\title{
Kinematical ANALYSIS OF THE MULTibOdY SYSTEMS USING TOPOLOGICAL DESCRIPTION
}

\author{
Vlase, S.; MunTEAnU, M.V. \& Scutaru, M.L.
}

Abstract: The paper aims to provide a structural description of flat mechanics by using the theory of graphs. Besides this description, fully defined by the incidence matrix (or by the equivalent basic cycle matrix), geometrical and kinematical description are also intended. The graph theory was used in the mechanical system analysis in two different ways: - in one way the constitutive elements of the system are considered nodes and the liaison between elements are considered edges. This analysis leads to the independent cycle method, developed by various authors in many variants; - another way is to consider the liaison between elements as nodes and the vector defined by the points of the liaison as edges. This description, less used in the literature permit to utilize the natural vector description of the system. The thus created formal framework allows representing the condition equations of speeds and accelerations suitable for numerical applications.

Key words: Graph Theory, Kinematics, Independent Cycle
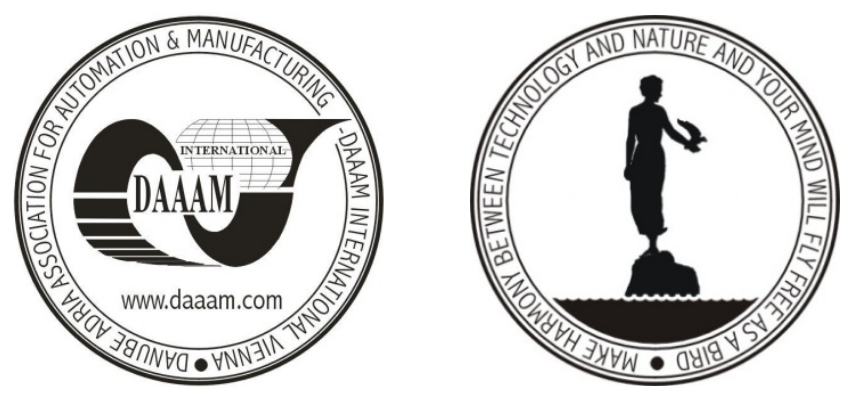

Authors' data: Prof.Dr.Eng. Vlase, S[orin]*; Assist. PhD. Student Munteanu, M[ihaela] V[ioleta]**; Dr. Assist. Dr. Eng. Scutaru, M[aria] L[uminita]***, *Transilvania University of Brasov, B-Dul Eroilor,29, 500036, Brasov, RO, **Transilvania University of Brasov, 5, Macesului Street, B1. A20, Sc. D, 500256, Brasov, RO, ***Transilvania University of Brasov, Romania, Str. Eroilor, Nr.29, 500412, Brasov, RO, svlase@unitbv.ro,v.munteanu@unitbv.ro, lscutaru@unitbv.ro

This Publication has to be referred as: Vlase, S[orin]; Munteanu, M[ihaela] V[ioleta] \& Scutaru, M[aria] L[uminita] (2008). Kinematical Analysis of the Multibody Systems Using Topological Description, Chapter 79 in DAAAM International Scientific Book 2008, pp. 953-966, B. Katalinic (Ed.), Published by DAAAM International, ISBN 978-3-901509-66-7, ISSN 1726-9687, Vienna, Austria DOI: $10.2507 /$ daaam.scibook.2008.79 